\title{
Water Relations of Salmonella oranienburg; Stimulation of Respiration by Amino Acids
}

\author{
By J. H. B. CHRISTIAN AND JUDITH A. WALTHO \\ Commonwealth Scientific and Industrial Research Organization, \\ Division of Food Preservation, North Ryde, N.S.W., Australia
}

(Received 7 October 1965)

\begin{abstract}
SUMMARY
The influence of amino acids on respiration of Salmonella oranienburg was studied over a range of water activity $\left(a_{\mathrm{w}}\right)$ values. Decrease of the $\mathrm{a}_{\mathrm{w}}$ value by adding $\mathrm{NaCl}$ or sucrose decreased the rate of glucose oxidation and induced a lag. At relatively low values $\left(0.970 \mathrm{a}_{\mathrm{w}}\right)$ but not at high values $\left(0.998 \mathrm{a}_{\mathrm{w}}\right)$, additions of certain amino acids (proline, aspartic acid, asparagine, glutamic acid, glutamine, cysteine) caused an appreciable synergistic increase in respiration rate. Proline was the most stimulatory amino acid tested. At $\mathbf{0 . 9 6 0} \mathrm{a}_{\mathrm{w}}$, only proline and its analogue azetidine2-carboxylic acid gave appreciable stimulation. These were the only amino acids which decreased the lag, and lags were not affected by the presence of chloramphenicol. Proline was also stimulatory when glucose was replaced by pyruvate or succinate. The respiration of organisms grown at low $a_{w}$ values was not stimulated by proline unless the organisms were first subjected to osmotic shock. The proline effect was also observed with bacteria of four other genera. The data are discussed in relation to the stimulation by proline of bacterial growth at low water activities.
\end{abstract}

\section{INTRODUCTION}

For most of the non-halophilic bacteria that have been studied the effects of high concentrations of various solutes upon growth are best described in terms of the water activity $\left(a_{w}\right)$ of the growth medium (Scott, 1957). The water relations of such organisms are thus largely independent of the nature of the solutes used to control the water activity. They may be greatly influenced, however, by the nutritional status of the environment (Christian, 1955a). The latter study showed that growth of Salmonella oranienburg occurred at much lower values of $\mathrm{a}_{\mathrm{w}}$ in complex media than in a simple glucose salts medium. Much of this difference was ascribed to several amino acids present in the complex medium. Proline was the most important of these, for, although it had a relatively small effect on growth at low $\mathbf{a}_{\mathbf{w}}$ values when added alone, its presence was essential to obtain marked stimulation by the other amino acids. This effect of proline on bacterial water requirements has not been explained. There is a marked similarity between the water relations of growth of $S$. oranienburg and the water relations of respiration (Christian, 1955b), suggesting that at low values of $a_{w}$ the rate of respiration might be the factor which limits the rate of growth. Thus it was of interest to determine whether proline and other amino acids which stimulate growth at low $a_{w}$ values also stimulate respiration 
under these conditions. The present paper reports results which show that proline stimulates respiration at low, but not at high, $a_{w}$ values, and that at low $a_{w}$ values the effect is highly specific for proline.

\section{METHODS}

Micro-organisms. The main test organism was a strain of Salmonella oranienburg studied previously (Christian, 1955 a). Some comparative experiments were made with one strain each of Escherichia coli, Pseudomonas fluorescens, Staphylococcus aureus, Vibrio costicolus and V. metchnikovi.

Media. For most experiments, organisms were grown in $100 \mathrm{ml}$. brain theart infusion (BH) broth in $250 \mathrm{ml}$. Erlenmeyer flasks shaken at $30^{\circ}$. The water activity $\left(a_{w}\right)$ of this medium was 0.993. A glucose + inorganic salts (GS) medium $\left(0.999 a_{w}\right.$; Christian, $1955 a$ ) was also used. In several experiments the $a_{w}$ value of these media was decreased to $\mathbf{0 . 9 7 0}$ by adding $\mathrm{NaCl}$ or sucrose. The halophile Vibrio costicolus was grown in the medium of Robinson \& Gibbons (1952).

Manometry. Organisms in the early stationary phase of growth were harvested

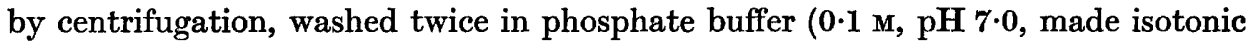
to the growth medium with $\mathrm{NaCl}$ where necessary), and suspended in the buffer. Warburg flasks contained, in the main compartment, 0.5 or $1.0 \mathrm{ml}$. of bacterial suspension, 100 p.p.m. chloramphenicol, and sufficient $\mathrm{NaCl}$ (or sucrose) solution to give the desired final water activity. The side arms contained $10 \mu$ moles glucose or $5 \mu$ moles of the L-isomer of amino acids, and the centre well $0.2 \mathrm{ml} .10 \%(\mathrm{w} / \mathrm{v})$ $\mathrm{KOH}$ (with folded filter paper except when ${ }^{14} \mathrm{CO}_{2}$ production was to be estimated). The total volume of reactant solutions was $3.0 \mathrm{ml}$. Flasks were tipped after equilibration for $10 \mathrm{~min}$. at $30^{\circ}$, and readings were taken at $10 \mathrm{~min}$. intervals.

To determine ${ }^{14} \mathrm{CO}_{2}$ production from $\left[{ }^{14} \mathrm{C}\right]$-labelled substrates, the reaction was stopped with $1.0 \mathrm{ml} . \mathrm{H}_{2} \mathrm{SO}_{4}$ from a side arm and, after shaking for $10 \mathrm{~min}$., $0.1 \mathrm{ml}$. of solution was transferred from the centre well to a filter-paper disc. After drying, the radioactivity of the disc was determined by liquid scintillation counting. Uniformly labelled $\left[{ }^{14} \mathrm{C}\right]$ glucose and $\left[{ }^{14} \mathrm{C}\right] \mathrm{L}$-proline were obtained from the Radiochemical Centre, Amersham, Buckinghamshire, England.

Dry weights of organism were determined on 5 ml. samples after washing duplicate centrifuge deposits with water and drying for $24 \mathrm{hr}$ at $100^{\circ}$. Rates of oxygen uptake were corrected for endogenous respiration and expressed as $Q_{0_{2}}$ values ( $\mu$ l. $\mathrm{O}_{2} / \mathrm{mg}$. dry wt. organism/hr.)

Analytical methods. Organisms were washed in isotonic $\mathrm{NaCl}$ solution and extracted with cold $10 \%(\mathrm{w} / \mathrm{v})$ trichloroacetic acid solution. Potassium was estimated by flame photometry. Total amino acid was determined by the method of Rosen (1957) with alanine as standard, and proline by the method of Troll \& Lindsley (1955) after shaking the extract with Dowex 50 resin to remove interfering amino acids.

\section{RESULTS}

\section{Oxidation of amino acids}

Twenty-three amino acids (including proline, hydroxyproline and azetidine-2carboxylic acid) were tested as substrates for the respiration of Salmonella oranienburg in the absence of salt $\left(0.998 a_{w}\right)$ and with salt added to give $0.970 a_{w}$. Table 1 
shows $Q_{\mathrm{O}_{2}}$ values for those amino acids which were oxidized at measurable rates, and for glucose. Decreasing the $a_{w}$ value substantially decreased the rate of respiration with all amino acids except proline. The proline analogue azetidine-2-carboxylic acid, was oxidized only slowly at both $\mathrm{a}_{\mathrm{w}}$ values.

\section{Table 1. Rates of oxidation of glucose and of amino acids by} Salmonella oranienburg at two $a_{w}$ values

\begin{tabular}{l}
\multicolumn{1}{c}{ Substrate } \\
Glucose \\
L-alanine \\
Asparagine \\
Aspartic acid \\
Azetidine-2-carboxylic acid \\
Cysteine \\
Glutamic acid \\
Glutamine \\
Glycine \\
Methionine \\
Proline \\
Serine \\
Threonine
\end{tabular}

$\overbrace{0.998 \mathrm{a}_{\mathrm{W}}}^{Q_{\mathrm{O}_{2}}} \begin{array}{cc}0 \cdot 970 \mathrm{a}_{\mathrm{W}} \\ 141 & 46 \\ 16 & 1 \\ 53 & 0 \\ 53 & 1 \\ 0 & 2 \\ 10 & 2 \\ 6 & 0 \\ 10 & 0 \\ 3 & 0 \\ 5 & 0 \\ 10 & 14 \\ 74 & 1 \\ 18 & 1\end{array}$

Amino acids which supported $\boldsymbol{Q}_{\mathrm{O}_{2}}$ values $<2$ at both $\mathbf{a}_{\mathrm{W}}$ values: arginine, histidine, hydroxyproline, isoleucine, leucine, lysine, norvaline, ornithine, phenylalanine, tryptophan, valine.

\section{Table 2. Oxidation of glucose + amino acids by Salmonella oranienburg at 0.970 and $0.960 a_{w}$}

\begin{tabular}{|c|c|c|c|c|}
\hline$a_{W}$ value & Substrate & $Q_{\mathrm{O}_{2}}$ & $\begin{array}{c}\% \boldsymbol{Q}_{\mathrm{O}_{2}} \\
\text { (glucose } \\
\text { + proline) }\end{array}$ & $\begin{array}{l}\text { Time to } \\
\text { attain } \\
\text { constant } \\
Q_{\mathrm{o}_{\mathrm{a}}}(\text { min.) }\end{array}$ \\
\hline \multirow[t]{8}{*}{$0 \cdot 970$} & $\begin{array}{l}\text { Glucose } \\
\text { Glucose }\end{array}$ & 46 & 38 & 98 \\
\hline & + proline & 121 & 100 & 47 \\
\hline & + aspartic acid & 101 & 83 & 93 \\
\hline & + asparagine & 96 & 79 & 98 \\
\hline & +glutamine & 81 & 67 & 92 \\
\hline & +cysteine & 81 & 67 & 108 \\
\hline & +azetidine-2-carboxylic acid & 78 & 65 & 63 \\
\hline & + glutamic acid & 74 & 61 & 105 \\
\hline \multirow[t]{7}{*}{$0 \cdot 960$} & Glucose & 14 & 28 & 220 \\
\hline & Glucose & & & \\
\hline & + proline & $\mathbf{5 0}$ & 100 & 70 \\
\hline & + azetidine-2-carboxylic acid & 41 & 82 & 120 \\
\hline & + aspartic acid & 22 & 44 & 220 \\
\hline & + cysteine & 20 & 40 & 230 \\
\hline & + glutamic acid & 17 & $\mathbf{3 4}$ & 220 \\
\hline
\end{tabular}

Oxidation of amino acids plus glucose at low water activities

In earlier studies (Christian, 1955a) the following rates of growth in generations per hr were obtained when various supplements were added to glucose salts medium at $0.970 \mathrm{a}_{\mathrm{w}}$ : no addition, $0 \cdot 10$; proline, 0.27 ; proline + methionine, 0.52 ; vitamin-free 
Casamino acids, $\mathbf{0} \cdot 61$. Thus most of the stimulation of growth provided by Casamino acids could be obtained with proline + methionine. To determine whether respiration was stimulated similarly, the oxidation of glucose, proline and methionine was

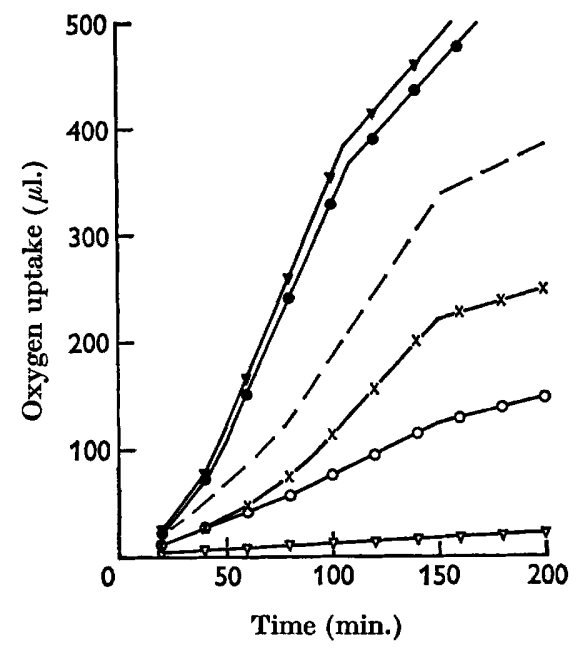

Fig. 1. Oxygen uptake at $0.970 \mathrm{a}_{\mathrm{w}}$ by Salmonella oranienburg organisms grown at $0.993 \mathrm{a}_{\mathrm{W}}$. Substrates: $\times$, glucose; $O$, proline; $\nabla$, methionine, $O$, glucose + proline; $\nabla$, glucose + proline + methionine. The broken line is the sum of individual values obtained with glucose and with proline.
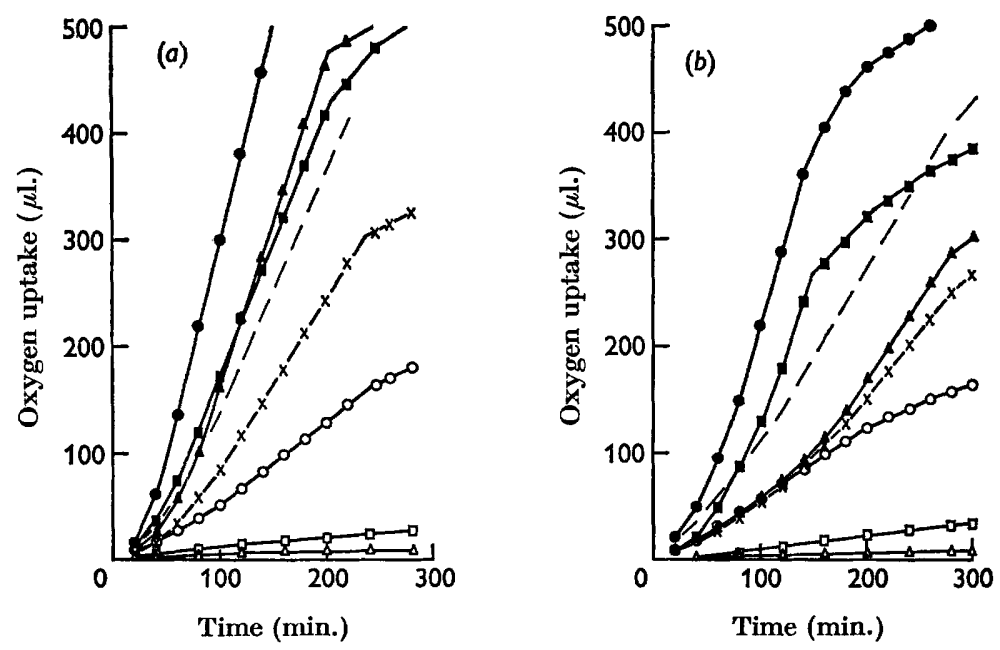

Fig. 2. Oxygen uptake at $(a) 0.970 \mathrm{a}_{\mathrm{w}}$ and $(b) 0.960 \mathrm{a}_{\mathrm{w}}$ by Salmonella oranienburg organisms grown at $0.993 \mathrm{a}_{\mathrm{w}}$. Substrates: $x$, glucose; $O$, proline; $\square$, azetidine-2carboxylic acid; $\triangle$, aspartic acid; $\bigcirc$, glucose + proline; $\boldsymbol{\omega}$, glucose + azetidine-2-carboxylic acid; $\Delta$, glucose + aspartic acid. The broken line is as in Fig. 1.

studied at $0.970 \mathrm{a}_{\mathrm{w}}$ (Fig. 1). The maximum rate of respiration with glucose + proline (i.e. both substrates provided together) was much greater than the sum of rates for the individual substrates. This synergism will be referred to as stimulation. In con- 
trast to its marked effect upon growth rate, methionine had little influence on respiration. Neither the long periods of accelerating respiration (the lags) nor the maximum rates of respiration were affected by the presence of 100 p.p.m. chloramphenicol. In the curves of Figs. 1 and 2, each alternate point has been omitted for clarity. The linear phase of respiration and the time at which it began were always well defined.

Table 2 shows the lags and respiration rates obtained at $a_{w} 0.970$ and 0.960 when various amino acids were joint substrates with glucose. The data are for mixtures which at $0.970 \mathrm{a}_{\mathrm{w}}$ gave $Q_{\mathrm{o}_{2}}$ values greater than $60 \%$ of that recorded with glucose +

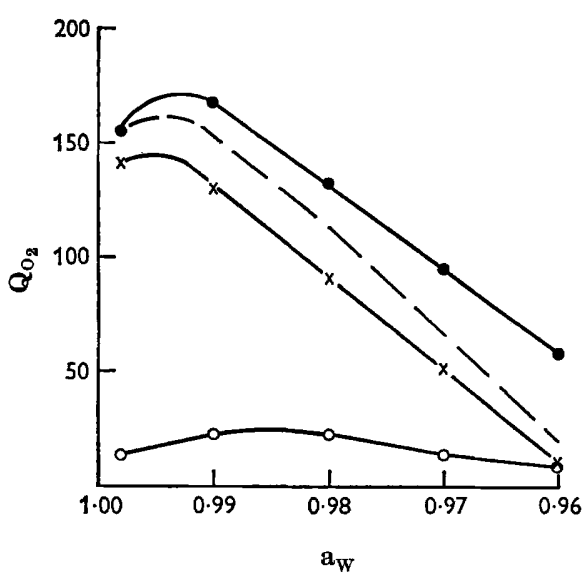

Fig. 3
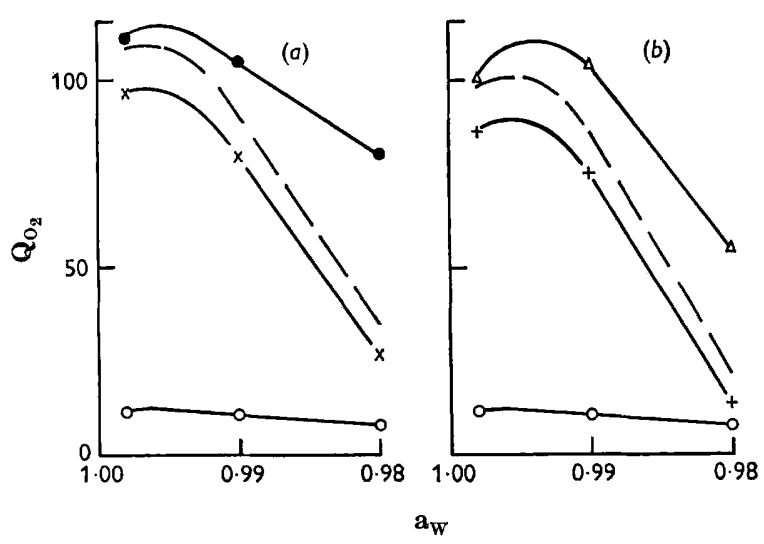

Fig. 4

Fig. 3. Relation between respiration rate and $\mathbf{a}_{\mathrm{w}}$ value for Salmonella oranienburg organisms grown at $0.993 \mathrm{a}_{\mathrm{W}}$. Substrates: $\times$, glucose; $O$, proline; $\bullet$, glucose + proline. The broken line is as in Fig. 1.

Fig. 4. Relation between respiration rate and $\mathrm{a}_{\mathrm{w}}$ value for Salmonella oranienburg organisms grown at $\mathbf{0 . 9 9 9} \mathrm{a}_{\mathrm{w}}$ in glucose salts medium. Substrates: $(a) \times$, glucose; $O$, proline; $O$, glucose + proline; $(b)+$, pyruvate; $O$, proline, $\Delta$, pyruvate + proline. The broken lines represent the sums of rates with the individual substrates.

proline. At $0.960 \mathrm{a}_{\mathrm{w}}$, rates with amines were similar to those with the corresponding dicarboxylic acids and have been omitted from Table 2 . Respiration curves for the most active mixtures of glucose + amino acid at these two $a_{w}$ values are shown in Fig. 2. Proline was the most stimulatory amino acid at both $a_{w}$ values, and azetidine-2-carboxylic acid was also prominent. As compared with other amino acids, these two compounds became relatively more stimulatory of $Q_{\mathrm{o}_{2}}$ as the $\mathrm{a}_{\mathrm{w}}$ value decreased. When added with glucose, only proline and its analogue gave respiratory lags which were appreciably less than that observed with glucose alone. Figure 2 shows graphically the much greater respiratory stimulation of these two amino acids at $0.960 \mathrm{a}_{\mathrm{w}}$ as compared with aspartic acid, the next most active compound tested.

\section{Water relations of oxidation of glucose and proline}

The influence of $a_{w}$ value on respiration with glucose and proline as substrates, individually and together, is shown in Fig. 3. The synergistic effect noted previously at low $a_{w}$ values with glucose + proline was not evident at $0.998 a_{w}$. At 
$0.990 \mathrm{a}_{\mathrm{w}}$ stimulation was appreciable and it approached $200 \%$ when the $\mathrm{a}_{\mathrm{w}}$ value was decreased to $0 \cdot 960$. The graph shows clearly the relatively low optimum water activity for proline oxidation.

With glucose or glucose + proline, the uptake of oxygen was linear virtually from the time of adding substrate when the $a_{\mathrm{w}}$ value was 0.980 or greater. As the water activity was decreased below $0 \cdot 980$, increasing lags were observed before linearity

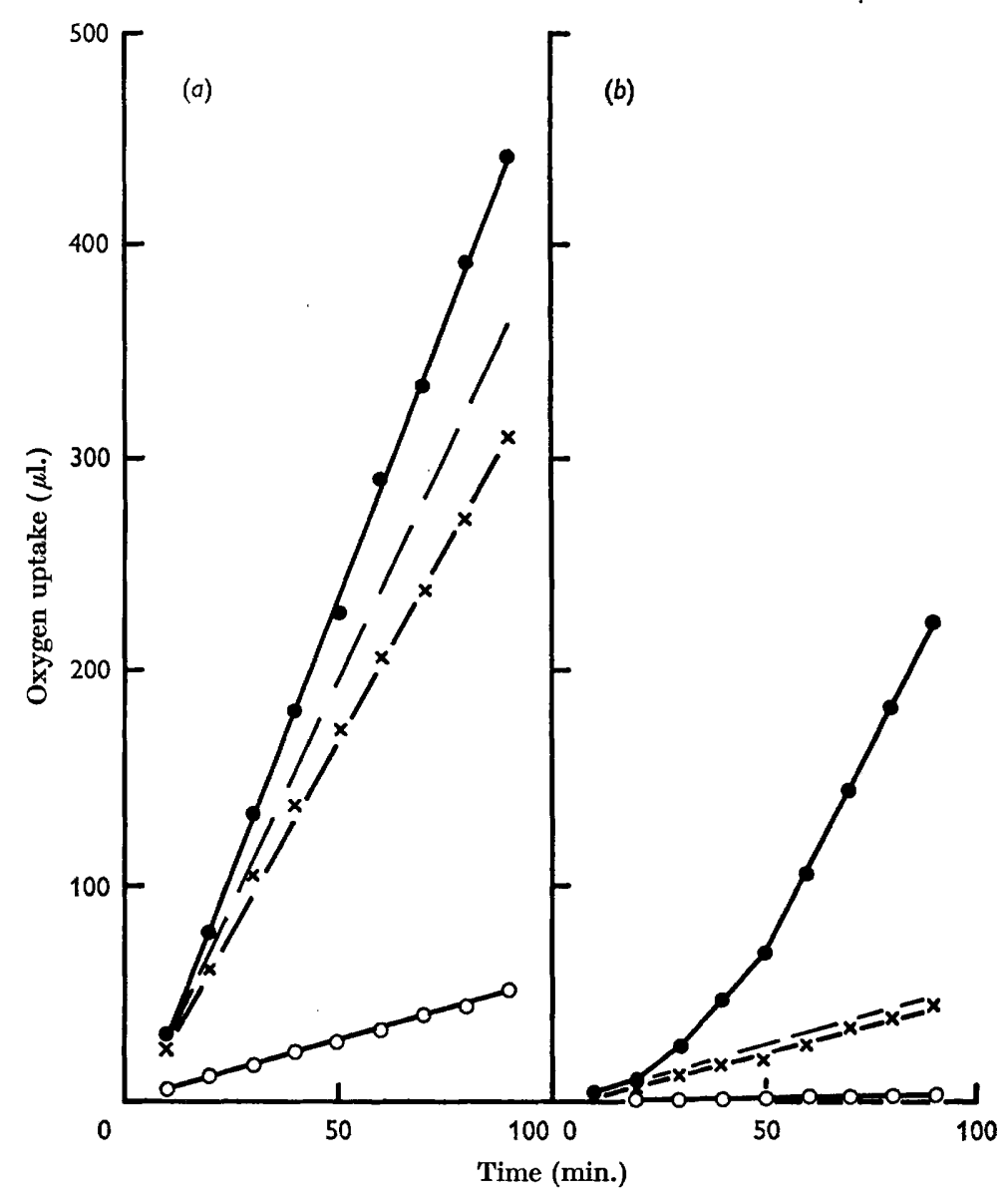

Fig. 5. Oxygen uptake at $0.970 \mathrm{a}_{\mathrm{w}}$ by Salmonella oranienburg organisms grown at $0.970 \mathrm{a}_{\mathrm{w}}$. (a) Organisms washed twice in phosphate buffer $+\mathrm{NaCl}\left(0.970 \mathrm{a}_{\mathrm{w}}\right)$; $(b)$ organisms washed twice in water. Substrates: $\times$, glucose; $O$, proline; $O$, glucose + proline. The broken lines are as in Fig. 1.

was achieved in the respiration curves (see Figs. 1 and 2). Proline respiration curves were linear from near the origin at all $a_{w}$ values tested $(0 \cdot 998-0.950)$, but the rate increased when oxygen consumption reached about $1 \mu$ atom $/ \mu$ mole proline (see Fig. 1). In all cases, $Q_{\mathrm{O}_{2}}$ (proline) refers to the higher rate. 


\section{Influence of the growth medium}

The data reported above were obtained with cells grown in brain + heart broth. Figure $4 a$ shows that the proline effect was also demonstrable with organisms grown in a proline-free environment, namely, glucose salts medium. Respiration was more sensitive to decreasing $a_{w}$ value than was the case with organisms grown on complex medium and the stimulatory effect of proline was relatively much greater.

\section{Effect of proline on respiration with other substrates}

The relatively high specificity of proline in stimulating respiration with glucose having been shown it was of interest to know whether glucose was also specific in this reaction. Figure $4 b$ shows that a similar effect was obtained when pyruvate and proline were the substrates. Stimulation was observed also with succinate + proline, but the rates were much lower than those obtained with pyruvate + proline, irrespective of whether the growth medium contained glucose or succinate as carbon source.

\section{Effect of solute used to adjust $a_{W}$ value}

In experiments described above the water activity was controlled by adding $\mathrm{NaCl}$. That $\mathrm{NaCl}$ did not have a specific effect upon respiration or on proline stimulation was shown by decreasing the $a_{w}$ value to 0.970 by adding sucrose: the $Q_{\mathrm{o}_{2}}$ values for the oxidation of glucose, proline and glucose + proline differed from those found in $\mathrm{NaCl}$ by less than $10 \%$.

\section{Respiration of organisms grown at low water activity}

Organisms which were grown in brain + heart broth adjusted to $0.970 \mathrm{a}_{\mathrm{w}}$ with $\mathrm{NaCl}$ and then washed in isotonic $\mathrm{NaCl}+$ phosphate buffer gave a pattern of respiration very different from that reported above. With all substrates, the oxygen consumption was linear from the start, and proline caused little stimulation (Fig. 5a). When organisms grown in this manner were shocked by washing in water before testing at $0.970 \mathrm{a}_{\mathrm{w}}$, proline oxidation was almost abolished, and the $\boldsymbol{Q}_{\mathrm{o}_{2}}$ (glucose) was decreased by $\mathbf{8 4} \%$. However, with glucose + proline as joint substrates, respiration was largely restored, $Q_{\mathrm{O}_{2}}$ (glucose + proline) being only $28 \%$ less than with unshocked organisms (Fig. $5 b$ ).

\section{Pre-incubation of organisms at $0.970 a_{W}$}

To examine the effects on respiration of prior exposure to proline, organisms grown at $0.993 \mathrm{a}_{\mathrm{w}}$ were incubated at $0.970 \mathrm{a}_{\mathrm{w}}$ in phosphate buffer and chloramphenicol, with glucose, proline or glucose + proline. Suspensions were shaken for $45 \mathrm{~min}$. at $30^{\circ}$. After washing the organisms in $0.970 \mathrm{a}_{\mathrm{w}} \mathrm{NaCl}$ solution, their respiration rates were measured with glucose and with glucose + proline as substrates. The results are given in Table 3. Pre-incubation with glucose + proline or with proline alone increased greatly the rate of glucose respiration and almost abolished the ability of proline to increase the $Q_{o_{2}}$ value with glucose present. The influence of pre-incubation without proline was much less marked.

Changes in the composition of these organisms during pre-incubation were studied by analysing trichloroacetic acid extracts of the organisms for potassium, proline 
and total amino acids. Table 4 shows that large increases occurred in the amounts of each of these components during incubation at $0.970 a_{w}$ with glucose + proline or with proline.

\section{Table 3. Effect of pre-incubation at $0.970 a_{W}$ on respiration rates} of Salmonella oranienburg at $0.970 a_{W}$

All pre-incubation media contained phosphate buffer, chloramphenicol and $\mathrm{NaCl}$.

\begin{tabular}{|c|c|c|c|}
\hline $\begin{array}{l}\text { Pre-incubation period } \\
\text { and substrate }\end{array}$ & $\begin{array}{c}Q_{\mathrm{O}_{2}} \\
\text { (glucose) }\end{array}$ & 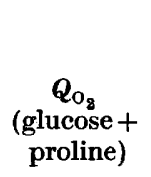 & $\begin{array}{c}\text { Increase } \\
\text { in } Q_{o_{2}} \text { in } \\
\text { presence } \\
\text { of proline } \\
(\%)\end{array}$ \\
\hline Nil & 86 & 159 & 85 \\
\hline 45 min.; glucose & 72 & 123 & 71 \\
\hline 45 min.; proline & 97 & 112 & 15 \\
\hline 45 min.; glucose + proline & 109 & 116 & 7 \\
\hline
\end{tabular}

Table 4. Effect of pre-incubation at $0.970 a_{W}$ on composition of Salmonella oranienburg organisms grown at $0.993 a_{W}$

Pre-incubation media as in Table $\mathbf{3}$

$\begin{array}{lccc}\quad \begin{array}{c}\text { Pre-incubation period } \\ \text { and substrate }\end{array} & \begin{array}{c}\text { Potassium } \\ \text { ( } \mu \text { equiv./g. })\end{array} & \begin{array}{c}\text { acids } \\ (\mu \text { moles/g. })\end{array} & \begin{array}{c}\text { Proline } \\ (\mu \text { moles/g. })\end{array} \\ \text { Nil } & 354 & 169 & 1 \\ 45 \text { min.; proline } & 855 & 661 & 60 \\ 45 \text { min.; glucose + proline } & 1029 & 451 & 158\end{array}$

\section{Oxidation of $\left[{ }^{14} \mathrm{C}\right]$-labelled substrates}

To determine whether respiratory stimulation resulted from increased rates of oxidation of glucose, of proline, or of both, manometric experiments were made with $\left[{ }^{14} \mathrm{C}\right]$-labelled substrates. In one set of experiments, the substrates were $\left[{ }^{14} \mathrm{C}\right]$ glucose and $\left[{ }^{12} \mathrm{C}\right]$ proline; in the other, $\left[{ }^{12} \mathrm{C}\right]$ glucose and $\left[{ }^{14} \mathrm{C}\right]$ proline. Oxygen consumption and ${ }^{14} \mathrm{CO}_{2}$ evolution were determined after incubation for 90-110 min. Table 5 shows that the synergistic increase in respiration when glucose + proline was present resulted from an increase in the rate of oxidation of each substrate. Further, these oxidation rates increased by the same factor, about $2 \cdot 4$-fold. In a confirmatory experiment, organisms were grown at $0.970 \mathrm{a}_{\mathrm{w}}$ and washed in water. This treatment decreased $Q_{\mathrm{o}_{3}}$ (glucose) at $0.970 \mathrm{a}_{\mathrm{w}}$ to 24 and $Q_{\mathrm{o}_{2}}$ (proline) to 1.5. As joint substrates, glucose + proline gave a $Q_{\mathrm{O}_{2}}$ value of 75, a three-fold stimulation. The production of ${ }^{14} \mathrm{CO}_{2}$ from $\left[{ }^{14} \mathrm{C}\right]$ proline was also increased threefold by the presence of glucose.

\section{Experiments with other bacteria}

The influence of proline on respiration at low values of water activity was examined with five species of bacteria from four other genera. Respiration with glucose by Pseudomonas fluorescens, Escherichia coli and Vibrio metchnikovi grown at $0.993 \mathrm{a}_{\mathrm{w}}$ was greatly stimulated by proline at $0.970 \mathrm{a}_{\mathrm{w}}$. Similarly, proline stimulated the respiration of the moderately halophilic Vibrio costicolus in $2 \mathrm{M}-\mathrm{NaCl}$ after growth in $\mathrm{M}-\mathrm{NaCl}$ medium. In contrast, Staphylococcus aureus grown in 
brain + heart broth $\left(0.993 \mathrm{a}_{\mathrm{w}}\right)$ showed little response to proline at decreased $\mathrm{a}_{\mathrm{w}}$ values. However, when the cocci were grown at $0.940 \mathrm{a}_{\mathrm{w}}$ and washed in water, a marked proline effect on respiration at $0.940 \mathrm{a}_{\mathrm{w}}$ was evident. The specificity of the stimulation by proline has not yet been examined with these bacteria.

Table 5 Stimulation of respiration of Salmonella oranienburg by glucose + proline at $0.97 a_{W}$

$\overbrace{\mathrm{O}_{2} \text { uptake }}^{\text {Stimulation* of }} \underbrace{}_{{ }^{14} \mathrm{CO}_{2} \text { evolution } \dagger}$

Substrates

$\left[{ }^{14} \mathrm{C}\right]$ glucose $\ddagger+\left[{ }^{12} \mathrm{C}\right]$ proline

Expt. 1

$\overbrace{\frac{305^{*}}{85+43}=2 \cdot 38 \quad \frac{32,918 \S}{13,821+0}=2 \cdot 38}^{10.9}$

Expt. 2

$\frac{318}{86+56}=2 \cdot 24$

$\frac{9,135}{3,945+0}=2 \cdot 32$

Expt. 3

$\frac{337}{87+44}=2 \cdot 57$

$\frac{1,326}{529+0}=2 \cdot 50$

Mean士s.E.

$2 \cdot 40 \pm 0 \cdot 12$

$2 \cdot 40 \pm 0 \cdot 06$

Substrates

$\left[{ }^{12} \mathrm{C}\right]$ glucose $+\left[{ }^{14} \mathrm{C}\right]$ proline $\ddagger$

Expt. 4

$\frac{301}{85+43}=2 \cdot 35$

$\frac{35,423}{0+10,720}=3 \cdot 30$

Expt. 5

$\frac{288}{102+16}=2 \cdot 44$

$\frac{23,160}{0+11,697}=1.98$

Expt. 6

$\frac{310}{86+56}=2 \cdot 18$

$\frac{7,993}{0+3,369}=2 \cdot 37$

Mean \pm s.E.

$2 \cdot 32 \pm 0 \cdot 07$

$\mathbf{2 \cdot 5 5} \pm \mathbf{0 . 3 9}$

* Stimulation $=\frac{\text { activity with (glucose }+ \text { proline) }}{\text { activity with glucose }+ \text { activity with proline }}$, where activity $=\mu \mathrm{l} . \mathrm{O}_{2}$ consumed, or radioactivity (counts/min.) of ${ }^{14} \mathrm{CO}_{2}$ evolved.

$\dagger$ Samples containing ${ }^{14} \mathrm{CO}_{2}$ in $\mathrm{KOH}$ were transferred to filter-paper discs, dried at $60^{\circ}$, placed in vials with $10 \mathrm{ml}$. 'Scinstant' scintillator NE 572 (Nuclear Enterprises G.B. Ltd., Edinburgh 11), and counted in a Packard Tricarb Scintillation Counter.

¥ Specific activities of substrates were changed for each experiment.

$\$$ Values are means of counts from duplicate flasks. Average variation of duplicates from the means was $3.9 \%$.

\section{DISCUSSION}

Proline was stimulatory only when Salmonella oranienburg was transferred to a hypertonic environment. Thus the respiration of organisms grown at $0.993 a_{\mathrm{w}}$ was stimulated at $0.970 \mathrm{a}_{\mathrm{w}}$ but not at $0.998 \mathrm{a}_{\mathrm{w}}$, and when grown at $0.970 \mathrm{a}_{\mathrm{w}}$, stimulation was not observed at $0.970 a_{w}$ unless the organisms had first been washed in water. It appears likely, therefore, that proline may play some role in overcoming the effects of shrinkage or plasmolysis on respiration.

The long periods of increasing respiration rate at low $a_{w}$ values were not due to the production of new enzymes, as they were unaffected by adding chloramphenicol, and in organisms grown at $0.970 \mathrm{a}_{\mathrm{w}}$ could be induced by washing with water. Miller, Avi-Dor \& Mager (1963) observed a similar lag during oxidation of glutamate by waterwashed Escherichia coli organisms and showed that its duration coincided with the formation of the maximum internal potassium pool. Christian (1955b) 
reported that Salmonella oranienburg accumulated increasing amounts of potassium during glucose respiration as the water activity was decreased. Hence the lag in glucose oxidation at low $a_{w}$ values probably represents the accumulation of potassium to a concentration which partially restores cell turgor.

Britten \& McClure (1962) found that with decreasing water activity there was a pronounced increase in proline uptake by Escherichia coli in a glucose salts medium containing proline. At about $0.970 \mathrm{a}_{\mathrm{w}}$, the organisms took up about $1 \mathrm{~m}$-mole proline/g. dry wt. organism, much of it being eventually converted to other amino acids. Superimposed on the potassium pool already discussed, such an amino acid pool would greatly decrease the intracellular water activity, thus assisting equilibration with the external environment. Table 4 shows that large increases in potassium and amino acids did occur during oxidation of glucose + proline at $0.970 \mathrm{a}_{\mathrm{w}}$.

Although at $0.970 a_{w}$ the $Q_{0_{2}}$ (glucose) value was much greater than the $Q_{0_{2}}$ (proline) value, tracer studies showed that each of these substrates stimulated the rate of oxidation of the other by the same factor. This also is most readily interpreted as an overall increase in respiratory metabolism resulting from osmotic equilibration, as described by Henneman \& Umbreit (1964).

There is as yet no explanation for the specificity of proline in stimulating respiration at low $a_{\mathrm{w}}$ values. The relatively high $Q_{\mathrm{o}_{2}}$ (proline) values at 0.970 and $0.960 \mathrm{a}_{\mathrm{w}}$ are not the reason, since azetidine-2-carboxylic acid, which also has a marked stimulatory effect, is oxidized extremely slowly. This analogue competes with proline for incorporation into bacterial protein (Fowden \& Richmond, 1963). It is likely that the proline specificity resides in the mechanism which transports proline (and azetidine-2-carboxylic acid) into the organism, for such biosynthetically related compounds as hydroxyproline, arginine and ornithine were not stimulatory.

The data obtained with other bacteria suggest that stimulation of respiration by proline may be a general phenomenon, but thus far the specificity of the effect has been examined only with Salmonella oranienburg. If proline stimulates by increasing the amino acid pool and hence decreasing the internal water activity, the need first to subject Staphylococcus aureus organisms to osmotic shock is probably explained by the very high amino acid (and potassium) pools found in these cocci after growth at all values of water activity (Christian \& Waltho, 1962, 1964).

This investigation arose from the observation that proline was necessary for the growth of Salmonella oranienburg at $a_{w}$ values below 0.970 , and that several other amino acids stimulated growth at low water activity values only when proline was present. The data reported here suggest that proline may increase the utilization and incorporation of these amino acids by increasing the supply of respiratory energy under such conditions.

The authors are indebted to Miss Helen English and Miss Janice Hinchy for skilful technical assistance. 


\section{REFERENCES}

Britten, R. J. \& McClure, F. T. (1962). The amino acid pool in Escherichia coli. Bact. Rev. 26, 292.

Christian, J. H. B. (1955a). The influence of nutrition on the water relations of Salmonella oranienburg. Aust. J. biol. Sci. 8, 75.

Christian, J. H. B. $(1955 b)$. The water relations of growth and respiration of Salmonella oranienburg at $30^{\circ}$ C. Aust. J. biol. Sci. 8, 490 .

Christian, J. H. B. \& Waltho, J. A. (1962). Solute concentrations within cells of halophilic and non-halophilic bacteria. Biochim. biophys. Acta, 65, 506.

Christian, J. H. B. \& Waltho, J. A. (1964). The composition of Staphylococcus aureus in relation to the water activity of the growth medium. J. gen. Microbiol. 35, 205.

Fowden, L. \& Richmond, M. H. (1963). Replacement of proline by azetidine-2-carboxylic acid during biosynthesis of protein. Biochim. biophys. Acta, 71, 459 .

Henneman, D. H. \& Umbreit, W. W. (1964). Influence of the physical state of the bacterial cell membrane upon the rate of respiration. $J$. Bact. 87, 1274.

Miller, S., Avi-Dor, Y. \& Mager, J. (1963). Studies on the mechanism of potassiumstimulated respiration in Escherichia coli. J. gen. Microbiol. 36, 123.

Robinson, J. \& Gibbons, N. E. (1952). The effect of salts on the growth of Micrococcus halodenitrificans n.sp. Can. J. Bot. 30, 147.

Rosen, H. (1957). A modified ninhydrin colorimetric analysis for amino acids. Archiv. Biochem. Biophys. 67, 10.

Scotт, W. J. (1957). Water relations of food spoilage micro-organisms. Advanc. Fd Res. 7, 83.

Trolu, W. \& Lindscey, J. (1955). A photometric method for the determination of proline. J. biol. Chem. 215, 655. 